\title{
Ohrarehun käyttö maitorotuisten sonnien loppukasvatuksessa
}

\author{
Arto Huuskonen ${ }^{1)}$, Hannele Khalili ${ }^{2)}$, Sirpa Lunki ${ }^{3}$ ja Asko Rantanen ${ }^{4)}$ \\ ${ }^{1)}$ Maa-ja elintarviketalouden tutkimuskeskus, Kotieläintuotannon tutkimus, Halolantie 31A, 71750 \\ Maaninka,arto.huuskonen@mtt.fi \\ ${ }^{2)}$ Maa-ja elintarviketalouden tutkimuskeskus, Kotieläintuotannon tutkimus, 31600 Jokioinen, \\ hannele.khalili@mtt.fi \\ ${ }^{3)}$ Maa- ja elintarviketalouden tutkimuskeskus, Kotieläintuotannon tutkimus, Tutkimusasemantie 15, \\ 92400 Ruukki,sirpa.lunki@mtt.fi \\ 4)Altia Corporation, Koskenkorvan tehdas,61330 Koskenkorva, asko.rantanen@altiacorporation.com
}

\section{Tiivistelmä}

Tutkimuksen tarkoituksena oli selvittää integroidun tärkkelys-etanoliteollisuuden sivutuotteena syntyvän ohrarehun käyttömahdollisuuksia kasvavien lihanautojen seosrehuruokinnassa. Maitorotuisten sonnien ruokintakoe toteutettiin MTT:n Ruukin toimipisteessä. Eläimiä oli yhteensä 32, joista 12 oli roduiltaan friisiläisiä (fr) ja 20 ayrshirejä (ay). Kokeen alkaessa sonnien keskimääräinen elopaino oli $261 \pm 34,0 \mathrm{~kg}$, ja ne olivat keskimäärin $195 \pm 5,2$ vuorokauden ikäisiä. Eläimet ryhmiteltiin elopainon ja rodun perusteella neljään blokkiin, joista ne sijoitettiin satunnaisesti neljälle eri koeruokinnalle. Koeruokinnat erosivat toisistaan väkirehuruokinnan koostumuksen osalta. Väkirehun osuus oli $55 \%$ päivittäisestä kuiva-aineen syönnistä kaikilla ruokinnoilla. Kontrolliruokinta (OR0) sisälsi ainoastaan nurmisäilörehua (46 \% kuiva-aineesta) ja ohraa (54\%) koko ruokintakokeen ajan. Kolmella muulla ruokinnalla (OR25, OR50 ja OR75) väkirehu sisälsi ohraa $50 \%$ kuiva-aineesta ja ohrarehua $50 \%$ kuiva-aineesta siihen saakka, kunnes sonnit saavuttivat $450 \mathrm{~kg}: n$ elopainon. Tämän jälkeen väkirehussa oli OR25-ruokinnalla ohraa $75 \%$ ja ohrarehua $25 \%$. Vastaavasti OR50-ruokinnalla sekä ohraa että ohrarehua oli $50 \%$ väkirehusta ja OR75-ruokinnalla ohraa oli $25 \%$ ja ohrarehua $75 \%$ väkirehun kuiva-aineesta $450 \mathrm{~kg}: n$ elopainosta ylöspäin. Koe toteutettiin seosrehuruokinnalla ja kokeen aikana sonnit saivat seosrehua vapaasti. Karkearehuna ruokinnassa käytettiin ensimmäisen sadon timoteinurminatasäilörehua. Väkirehuna käytettiin litistettyä ohraa sekä Altian pelletöityä ohrarehua.

Sonnien rehun syönti oli kokeen aikana keskimäärin $9,53 \mathrm{~kg} k \mathrm{ka} / \mathrm{pv}$. Ohran osittainen korvaaminen ohrarehulla vaikutti rehun syöntiin käyräviivaisesti $(\mathrm{P}<0,05)$ koko koeajalle laskettuna. Rehun syönti lisääntyi, kun ohrasta 25 tai $50 \%$ korvattiin ohrarehulla. Sen sijaan $75 \%$ :n ohrarehun osuus aiheutti rehun syönnin vähenemisen OR0-ruokintaan verrattuna. Sonnien keskimääräinen päiväkasvu koko koeajalla oli 1244 g/pv ja nettokasvu $688 \mathrm{~g} / \mathrm{pv}$. Ohran osittainen korvaaminen ohrarehulla johti päivä- ja nettokasvutulosten lineaariseen heikkenemiseen (päiväkasvu $\mathrm{P}<0,05$ ); nettokasvu $\mathrm{P}<0,01$ ) keskimäärin kokeen aikana. Kasvutulokset olivat selkeästi heikoimmat, kun $75 \%$ ohrasta korvattiin ohrarehulla, ja $25 \%$ ja $50 \%$ :n tasoilla kasvut eivät juuri poikenneet ohraruokinnasta. Teurasprosentti ja ruhojen rasvaisuus pienenivät lineaarisesti $(\mathrm{P}<0,05)$, kun ohraa korvattiin ohrarehulla. Sen sijaan ruhojen lihakkuuteen ohrarehun osuudella oli käyräviivainen vaikutus $(\mathrm{P}<0,05)$ : ohrarehutasoilla 25 ja $50 \%$ lihakkuus näytti hieman paranevan ohraruokintaan verrattuna, mutta $75 \%$ :n ohrarehutasolla lihakkuus oli heikoin.

Ohrarehu osoittautui käyttökelpoiseksi energiarehuksi kasvaville lihanaudoille säilörehuohrapohjaisella ruokinnalla. Tutkimustulosten perusteella näyttäisi olevan realistista korvata puolet kasvavan lihanaudan väkirehuannoksesta ohrarehulla. Naudanlihantuottajan kannalta ohrarehun käyttö ruokinnassa muodostuu taloudellisesti järkeväksi, jos sen hinta suhteessa tuotantovaikutukseen on edullisempi kuin muiden käytettävissä olevien väkirehujen.

Asiasanat: naudanlihantuotanto, sonnit, rehut, ohrarehu, seosrehuruokinta 


\section{Johdanto}

Maa- ja elintarviketalouden tutkimuskeskuksen (MTT) koordinoimassa "Vilja rehuksi suoraan tiloilla" -hankkeessa selvitettiin teollisuuden sivutuotteiden käyttömahdollisuuksia naudanlihantuotannossa. Tämän tutkimuksen tarkoituksena oli selvittää integroidun tärkkelys-etanoliteollisuuden sivutuotteena syntyvän ohrarehun käyttömahdollisuuksia kasvavien lihanautojen seosrehuruokinnassa. Tutkimus toteutettiin MTT:n ja Altia Oyj:n yhteistyönä. Hanketta rahoittivat Pohjois-Pohjanmaan TE-keskus EMOTR-ohjelman kautta, MTT ja Altia Oyj.

\section{Aineisto ja menetelmät}

Maitorotuisten sonnien ruokintakoe toteutettiin MTT:n Ruukin toimipisteessä. Eläimiä oli yhteensä 32, joista 12 oli roduiltaan friisiläisiä (fr) ja 20 ayrshirejä (ay). Kokeen alkaessa eläimet siirrettiin vasikkakasvatustiloista parsinavettaan, jossa ne kytkettiin parteen. Järjestelyllä saatiin eläinkohtaisia havaintoja. Kokeen alkaessa sonnien keskimääräinen elopaino oli $261 \pm 34,0 \mathrm{~kg}$, ja ne olivat keskimäärin $195 \pm 5,2$ vuorokauden ikäisiä. Eläimet ryhmiteltiin elopainon ja rodun perusteella neljään blokkiin, joista ne sijoitettiin satunnaisesti neljälle eri koeruokinnalle. Koeruokinnat erosivat toisistaan väkirehuruokinnan koostumuksen osalta (Taulukko 1). Väkirehun osuus oli $55 \%$ päivittäisestä kuivaaineen syönnistä kaikilla ruokinnoilla. Kontrolliruokinta (OR0) sisälsi ainoastaan nurmisäilörehua (46 $\%$ kuiva-aineesta) ja ohraa (54\%) koko ruokintakokeen ajan. Kolmella muulla ruokinnalla (OR25, OR50 ja OR75) väkirehu sisälsi ohraa $50 \%$ kuiva-aineesta ja ohrarehua $50 \%$ kuiva-aineesta siihen saakka, kunnes sonnit saavuttivat $450 \mathrm{~kg}: \mathrm{n}$ elopainon. Tämän jälkeen väkirehussa oli OR25ruokinnalla ohraa $75 \%$ ja ohrarehua $25 \%$. Vastaavasti OR50-ruokinnalla sekä ohraa että ohrarehua oli $50 \%$ väkirehusta ja OR75-ruokinnalla ohraa oli $25 \%$ ja ohrarehua $75 \%$ väkirehun kuiva-aineesta 450 kg:n elopainosta ylöspäin (Taulukko 1).

Taulukko 1. Koeruokinnat ja rehuseokset (\% kuiva-aineesta).

\begin{tabular}{|l|l|l|l|l|}
\hline & \multicolumn{1}{|c|}{ OR0 } & \multicolumn{1}{c|}{ OR25 } & \multicolumn{1}{c|}{ OR50 } & \multicolumn{1}{c|}{ OR75 } \\
\hline Elopaino & Säilörehu (46) & Säilörehu (46) & Säilörehu (46) & Säilörehu (46) \\
& Ohra (54) & Ohra (27) & Ohra (27) & Ohra (27) \\
& Ohrarehu (0) & Ohrarehu (27) & Ohrarehu (27) & Ohrarehu (27) \\
\hline $\begin{array}{l}\text { Elopaino } \\
450-650 ~ k g\end{array}$ & Säilörehu (46) & Säilörehu (46) & Säilörehu (46) & Säilörehu (46) \\
& Ohra (54) & Ohra (40,5) & Ohra (27) & Ohra (13,5) \\
& Ohrarehu (0) & Ohrarehu (13,5) & Ohrarehu (27) & Ohrarehu (40,5) \\
\hline
\end{tabular}

Koe toteutettiin seosrehuruokinnalla ja kokeen aikana sonnit saivat seosrehua vapaasti. Karkearehuna ruokinnassa käytettiin ensimmäisen sadon timotei-nurminatasäilörehua. Väkirehuna käytettiin litistettyä ohraa sekä Altian pelletöityä ohrarehua. Lisäksi huolehdittiin vitamiinien ja kivennäisten saannista. Ruokinta tapahtui kolmesti päivässä; noin kello 08:00, 12:00 ja 18:00. Jäännösrehut punnittiin joka aamu. Kokeen aikana OR75-ryhmästä piti poistaa yksi ay-rotuinen sonni juoksutusmahaongelmien vuoksi. Sonnit punnittiin neljän viikon välein. Kokeen alussa ja lopussa eläimet punnittiin kahtena päivänä peräkkäin, jolloin kokeen alku- ja loppupaino määritettiin kahden päivän punnitusten keskiarvona. Sonnit teurastettiin kolmessa eri erässä, kun elopaino oli keskimäärin $650 \mathrm{~kg}$ ja sonnit olivat olleet kokeessa 268, 316 tai 345 päivää. Sonnien päiväkasvu laskettiin loppupainon ja kokeen alun painon erotuksena jaettuna kasvatuspäivillä. Nettokasvu laskettiin teuraspainon ja kokeen alun ruhopainon erotuksena jaettuna kasvatuspäivillä. Ruhopainona kokeen alussa käytettiin elopaino x 0,48. Teurasruhot luokiteltiin EUROP - luokituksen mukaisesti.

Säilörehusta kerättiin näytettä, joka yhdistettiin vastaamaan kunkin ruokintajakson (4 viikkoa) aikana syötettyä säilörehua. Ohrasta ja kivennäisestä näytteet otettiin jokaisesta erästä (siilo/säkki). Ohran ja kivennäisen analyysinäytteenä käytettiin kahden ruokintajakson aikana kerätyistä osanäytteistä yhdistettyjä kokonaisnäytteitä. Rehunäytteistä määritettiin kuiva-aine, tuhka, raakavalkuainen ja neutraalidetergenttikuitu MTT:1lä käytössä olevin standardimenetelmin (ks. esim. Huuskonen ym. 2007). Rehujen rasvapitoisuus määritettiin AOAC:n (1990) (procedure 920.39) mukaan. Tärkkelys analysoitiin McClearyn ym. (1994) mukaan. Säilörehun D-arvo mitattiin NIR-menetelmällä (Nousiainen ym. 2004). Säilörehusta määritettiin käymislaatu Valio Oy:ssä käytössä olevalla puristenestetitraukseen pohjautuvalla laatumäärityksellä (Moisio ja Heikonen 1989). Rehujen sisältämä muuntokelpoisen energian (ME) pitoisuus laskettiin rehutaulukoissa kuvatuilla menetelmillä (MTT 
2006). Rehuyksikköarvot (ry) laskettiin jakamalla ME-arvo 11,7:1lä. Ohutsuolesta imeytyvien aminohappojen (OIV) saanti ja rehujen OIV-arvot laskettiin Suomen olosuhteisiin muunnetun pohjoismaisen valkuaisarvojärjestelmän mukaisesti (MTT 2006). Ruokintojen näennäinen in vivo -sulavuus määritettiin kaikilta sonneilta AIA -menetelmällä (Van Keulen ja Young 1977) 5.4.-9.4.2006 välisenä aikana. Sulavuuskoe suoritettiin eläinten keskimääräisen elopainon ollessa $529 \mathrm{~kg}$.

Tilastollisen testauksen koemalli oli lohkoittain satunnaistettu koe, jossa havaintoyksikkönä oli eläin. Tulosten tilastollisena käsittelynä tehtiin varianssianalyysi SAS-ohjelmiston GLMproseduurilla. Testauksessa käytetty koemalli oli: $y_{i j k}=\mu+B_{j}+R_{i}+e_{i j k}$, missä $\mu$ on yleiskeskiarvo, $B_{j}$ on lohkon vaikutus $(j=1, \ldots, 4)$ ja $e_{i j k}$ on virhetermi. $R_{i}$ on koeruokinnan vaikutus. Jokainen lohko sisältää kaksi eläintä $(\mathrm{k}=1,2)$ samalta koeruokinnalta. Ohrarehulisäyksen vaikutus jaettiin ortogonaalisin kontrastein seuraaviksi vertailuiksi: 1) ohrarehulisäyksen lineaarinen vaikutus, 2) ohrarehulisäyksen toisen asteen vaikutus ja 3) ohrarehulisäyksen kolmannen asteen vaikutus. Käsittelykeskiarvojen väliset tilastolliset merkitsevyydet on ilmoitettu seuraavasti: $\mathrm{P}<0,001 * * *$ erittäin merkitsevä ero, $\mathrm{P}<0,01$ ** hyvin merkitsevä ero, $\mathrm{P}<0,05 *$ merkitsevä ero ja $\mathrm{P}<0,10$ o oli suuntaa-antava ero.

\section{Tulokset}

Kokeessa käytettyjen rehujen kemiallinen koostumus, rehuarvot sekä säilörehun säilönnällinen laatu on esitetty taulukossa 2. Säilörehun sulavuus oli kokeen aikana hyvä (D-arvo 69). Kokeessa käytetty ohra oli rehuarvoltaan hyvää. Ohrarehussa oli enemmän tuhkaa, raakavalkuaista ja rasvaa sekä selvästi enemmän NDF-kuitua kuin ohrassa. Ohrassa oli puolestaan selkeästi enemmän tärkkelystä kuin ohrarehussa. Suuremmasta kuitupitoisuudesta johtuen ohrarehun energia-arvo oli $14 \%$ ohraa matalampi.

Taulukko 2. Rehujen kemiallinen koostumus ja rehuarvo.

\begin{tabular}{lccc}
\hline & Säilörehu & Ohra & Ohrarehu \\
\hline Kuiva-aine (g/kg) & 285 & 887 & 921 \\
Kuiva-aineessa (g/kg) & & & \\
$\quad$ Orgaaninen aine & 914 & 977 & 963 \\
Raakavalkuainen & 170 & 131 & 139 \\
NDF & 548 & 220 & 601 \\
Tärkkelys & $\mathrm{ND}^{\mathrm{a}}$ & 535 & 71 \\
$\quad$ Rasva & $\mathrm{ND}$ & 22 & 65 \\
D-arvo (g/kg ka) & 693 & $\mathrm{ND}$ & $\mathrm{ND}$ \\
RY-arvo (ry/kg ka) & 0,95 & 1,13 & 0,99 \\
OIV (g/kg ka) & 87 & 106 & 96 \\
Hehtolitrapaino (kg/hl) & & 65 & \\
Säilörehun säilönnällinen laatu & & & \\
pH & 4,3 & & \\
Haihtuvat rasvahapot (g/kg ka) & 16 & & \\
Maito- ja muurahaishappo (g/kg ka) & 42 & & \\
Sokerit (g/kg ka) & 60 & & \\
Kokonaistypestä, g/kg N & & & \\
$\quad$ Ammonium typpi & 75 & & \\
$\quad$ Liukoinen typpi & 552 & & \\
\hline
\end{tabular}

${ }^{a}$ Ei määritetty.

Taulukko 3. Kokeessa käytettyjen rehuseosten kemiallinen koostumus ja rehuarvo.

\begin{tabular}{lcccc}
\hline & & \multicolumn{3}{c}{ Seos $^{\text {a }}$} \\
& OR0 & OR25 & OR50 & OR75 \\
\hline Kuiva-aine (g/kg) & 455 & 456 & 457 & 458 \\
Kuiva-aineessa (g/kg) & & & & \\
$\quad$ Orgaaninen aine & 949 & 947 & 945 & 943 \\
Raakavalkuainen & 149 & 150 & 151 & 152 \\
NDF & 368 & 420 & 472 & 525 \\
Tärkkelys & 299 & 234 & 170 & 106 \\
Rasva & 28 & 34 & 40 & 46 \\
RY-arvo (ry/kg ka) & 1,05 & 1,03 & 1,01 & 0,99 \\
OIV (g/kg ka) & 97 & 96 & 95 & 93 \\
\hline Koerukinnat on & & & &
\end{tabular}

\footnotetext{
${ }^{\mathrm{a}}$ Koeruokinnat on esitetty taulukossa 1 .
} 
Kokeessa käytettyjen rehuseosten koostumukset ja rehuarvot on ilmoitettu taulukossa 3. Erot ohrarehun ja ohran kemiallisissa koostumuksissa näkyivät luonnollisesti myös seosten koostumuksissa. Korvattaessa ohraa ohrarehulla seoksen NDF-pitoisuus nousi selkeästi ja vastaavasti tärkkelyspitoisuus aleni. Seoksen energiaväkevyys pieneni ja rasvapitoisuus nousi korvattaessa ohraa ohrarehulla.

Sonnien rehun syönti oli kokeen aikana keskimäärin $9,53 \mathrm{~kg} \mathrm{ka} / \mathrm{pv}$. Ohran osittainen korvaaminen ohrarehulla vaikutti rehun syöntiin käyräviivaisesti $(\mathrm{P}<0,05)$ koko koeajalle laskettuna (Taulukko 4). Rehun syönti lisääntyi, kun ohrasta 25 tai 50 \% korvattiin ohrarehulla. Sen sijaan $75 \%$ :n ohrarehun osuus aiheutti rehun syönnin vähenemisen OR0-ruokintaan verrattuna. Sama käyräviivainen vaikutus oli merkitsevä $(\mathrm{P}<0,05)$ myös OIV:n ja energian saannissa koko koeajalle laskettuna. Kokeen ensimmäisellä puoliskolla (eläinten elopaino alle $450 \mathrm{~kg}$ ) sonnien rehun syönnissä eikä energian tai OIV:n saannissa ollut eroja ruokintaryhmien välillä (Taulukko 5). Tällöin kontrolliryhmä sai väkirehuna pelkkää ohraa ja muut kolme ryhmää saivat väkirehuna ohran ja ohrarehun seosta samassa suhteessa (50:50 kuiva-aineesta). Kokeen jälkimmäisellä puoliskolla (eläinten elopaino yli $450 \mathrm{~kg}$ ) rehun syönnissä ja ravintoaineiden saannissa oli selkeitä eroja ruokintojen välillä (Taulukko 6), mikä on luonnollista, koska tällöin koeruokinnat olivat eriytyneet myös eri ohrarehutasojen osalta. Rehun syönnissä ja ravintoaineiden saannissa havaittiin kokeen jälkimmäisellä puoliskolla pääosin samat vaikutukset, jotka olivat nähtävissä keskimäärin koko koeajalta lasketuissa tuloksissa (Taulukko 4).

Ruokintojen näennäisissä in vivo -sulavuuksissa oli selkeitä eroja koeruokintojen välillä (Taulukko 6). Orgaanisen aineen sulavuus heikkeni lineaarisesti $(\mathrm{P}<0,001)$ korvattaessa ohraa ohrarehulla. Ohraruokintaan verrattuna dieetin orgaanisen aineen sulavuus heikkeni $17 \%$, kun ohrasta $75 \%$ korvattiin ohrarehulla. Myös dieetin raakavalkuaisen sulavuus heikkeni lineaarisesti korvattaessa ohraa ohrarehulla $(\mathrm{P}>0,01)$, mutta vaikutus ei ollut yhtä suuri kuin orgaanisen aineen osalta. Ohraruokintaan verrattuna dieetin raakavalkuaisen sulavuus heikkeni $3 \%$, kun ohrasta $75 \%$ korvattiin ohrarehulla. Dieetin NDF:n sulavuus heikkeni ohrarehun osuuden lisääntyessä ruokinnassa; sekä lineaarinen $(\mathrm{P}>0,001)$ että toisen asteen vaikutus $(\mathrm{P}>0,05)$ olivat tilastollisesti merkitseviä. Merkitsevä toisen asteen vaikutus kertoo, että kuidun sulatuksen heikkeneminen hidastui ohrarehun osuuden kasvaessa.

Taulukko 4. Rehun syönti, kasvu ja rehun hyväksikäyttö keskimäärin koko kokeen aikana sekä teurasdata.

\begin{tabular}{|c|c|c|c|c|c|c|c|c|}
\hline & \multicolumn{4}{|c|}{ Ruokinnat $^{\text {a }}$} & \multirow[t]{2}{*}{$\mathrm{SEM}^{\mathrm{b}}$} & \multicolumn{3}{|c|}{ Tilastollinen merkitsevyys ${ }^{c}$} \\
\hline & OR0 & OR25 & OR50 & OR75 & & 1 & 2 & 3 \\
\hline Jakson kesto (vrk) & 313 & 307 & 314 & 329 & & & & \\
\hline Rehun syönti (kg ka/pv) & 9,34 & 9,76 & 9,95 & 9,08 & 0,287 & & $*$ & \\
\hline Ry-saanti (ry/pv) & 9,81 & 9,99 & 10,06 & 9,07 & 0,298 & & $*$ & \\
\hline Oiv-saanti (g/pv) & 907 & 935 & 946 & 857 & 27,5 & & $*$ & \\
\hline Alkupaino (kg) & 260 & 260 & 261 & 265 & 5,7 & & & \\
\hline Loppupaino (kg) & 659 & 644 & 659 & 637 & 11,8 & & & \\
\hline Päiväkasvu (g/d) & 1288 & 1260 & 1279 & 1136 & 50,5 & $*$ & & \\
\hline Nettokasvu (g/d) & 721 & 720 & 690 & 614 & 24,7 & $* *$ & & \\
\hline \multicolumn{9}{|l|}{ Rehun hyväksikäyttö } \\
\hline $\mathrm{kg} \mathrm{ka/nettokasvu-kg}$ & 12,96 & 13,55 & 14,50 & 14,87 & 0,423 & $* *$ & & \\
\hline ry/nettokasvu-kg & 13,62 & 13,87 & 14,67 & 14,85 & 0,428 & $*$ & & \\
\hline \multicolumn{9}{|l|}{ Teurastulokset } \\
\hline Teuraspaino (kg) & 350 & 346 & 342 & 330 & 6,7 & $*$ & & \\
\hline Teurasprosentti $(\mathrm{g} / \mathrm{kg})$ & 532 & 538 & 519 & 518 & 6,5 & $*$ & & \\
\hline Lihakkuus (EUROP) $^{\text {d }}$ & 4,0 & 4,5 & 4,4 & 3,3 & 0,34 & & $*$ & \\
\hline Rasvaisuus (EUROP) $^{\mathrm{e}}$ & 3,3 & 3,0 & 3,0 & 2,7 & 0,16 & $*$ & & \\
\hline
\end{tabular}

${ }^{a}$ Koeruokinnat on esitetty taulukossa 1.

${ }^{\mathrm{b}}$ Keskiarvon keskivirhe.

${ }^{\mathrm{c}}$ Kontrastit: 1 = ohrarehun lineaarinen vaikutus; $2=$ ohrarehun toisen asteen vaikutus; $3=$ ohrarehun kolmannen asteen vaikutus. Tilastollinen merkitsevyys: *** $\mathrm{P}<0,001$; ** $\mathrm{P}<0,01 ; * \mathrm{P}<0,05$; o $\mathrm{P}<0,10$.

${ }^{\mathrm{d}}$ EUROP-laatuluokat: $\mathrm{O}-=4, \mathrm{O}=5, \mathrm{O}+=6$.

${ }^{\mathrm{e}}$ EUROP-rasvaisuusasteet: $1=$ rasvaton, 2 = ohutrasvainen, 3 = keskirasvainen, 4 = ylirasvainen, $5=$ erittäin rasvainen.

Sonnit painoivat kokeen lopussa keskimääräinen $650 \mathrm{~kg}$ ja niiden teuraspaino oli $342 \mathrm{~kg}$. Keskimääräinen päiväkasvu koko koeajalla oli $1244 \mathrm{~g} / \mathrm{pv}$ ja nettokasvu $688 \mathrm{~g} / \mathrm{pv}$. Ohran osittainen korvaaminen 
ohrarehulla johti päivä- ja nettokasvutulosten lineaariseen heikkenemiseen (päiväkasvu $\mathrm{P}<0,05$ ); nettokasvu $\mathrm{P}<0,01$ ) keskimäärin kokeen aikana (Taulukko 4). Kasvutulokset olivat selkeästi heikoimmat, kun $75 \%$ ohrasta korvattiin ohrarehulla, ja $25 \%$ ja $50 \%$ :n tasoilla kasvut eivät juuri poikenneet ohraruokinnasta. Kokeen ensimmäisellä puoliskolla ruokintojen välillä ei ollut eroa päiväkasvuissa (Taulukko 5), mutta jälkimmäisellä päiväkasvu heikkeni lineaarisesti $(\mathrm{P}<0,05)$ korvattaessa ohraa ohrarehulla (Taulukko 6). Heikko kasvutulos 75 \%:n korvaustasolla on nähtävissä myös eläinten elopainon kehitystä kuvaavasta käyrästä (Kuva 1). Sen sijaan elopainokäyrät olivat hyvin samankaltaisia ohrarehutasoilla 0,25 ja $50 \%$. Ohran korvaaminen ohrarehulla heikensi jonkin verran rehun hyväksikäyttöä kokeen aikana (Taulukko 4). Tämä trendi oli nähtävissä ennen kaikkea nettokasvukiloa kohti lasketuissa rehun hyväksikäyttöä kuvaavissa tunnusluvuissa. Koeruokinnoilla oli vaikutusta myös teurastuloksiin (Taulukko 4). Teurasprosentti ja ruhojen rasvaisuus pienenivät lineaarisesti $(\mathrm{P}<0,05)$, kun ohraa korvattiin ohrarehulla. Sen sijaan ruhojen lihakkuuteen ohrarehun osuudella oli käyräviivainen vaikutus $(\mathrm{P}<0,05)$ : ohrarehutasoilla 25 ja $50 \%$ lihakkuus näytti hieman paranevan ohraruokintaan verrattuna, mutta $75 \%$ :n ohrarehutasolla lihakkuus oli heikoin.

Taulukko 5. Päiväkasvu, rehun syönti, energian ja valkuaisen saanti sekä rehun hyväksikäyttö ruokintajaksolla 1 (alle $450 \mathrm{~kg}: \mathrm{n}$ elopainossa).

\begin{tabular}{|c|c|c|c|c|}
\hline & \multicolumn{2}{|c|}{ Ruokinnat $^{\mathrm{a}}$} & \multirow[t]{2}{*}{$\mathrm{SEM}^{\mathrm{b}}$} & \multirow[t]{2}{*}{ Tilastollinen merkitsevyys ${ }^{c}$} \\
\hline & OR0 & OR50 & & \\
\hline Eläinmäärä (kpl) & 8 & 23 & & \\
\hline Jakson kesto (vrk) & 139 & 139 & & \\
\hline Rehun syönti (kg ka/pv) & 8,02 & 8,44 & 0,304 & \\
\hline Ry-saanti (ry/pv) & 8,49 & 8,61 & 0,313 & \\
\hline Oiv-saanti (g/pv) & 774 & 804 & 29,2 & \\
\hline Päiväkasvu (g/pv) & 1365 & 1358 & 47,6 & \\
\hline \multicolumn{5}{|l|}{ Rehun hyväksikäyttö } \\
\hline kg ka/päiväkasvu-kg & 5,87 & 6,22 & 0,176 & o \\
\hline ry/päiväkasvu-kg & 6,22 & 6,34 & 0,180 & \\
\hline OIV g/päiväkasvu-kg & 567 & 593 & 16,9 & \\
\hline
\end{tabular}

${ }^{a}$ Koeruokinnat on esitetty taulukossa 1.

${ }^{\mathrm{b}}$ Keskiarvon keskivirhe.

${ }^{c}$ Tilastollinen merkitsevyys: *** $\mathrm{P}<0,001 ; * * \mathrm{P}<0,01 ; * \mathrm{P}<0,05$; o $\mathrm{P}<0,10$.

Taulukko 6. Päiväkasvu, rehun syönti, energian ja valkuaisen saanti, rehun hyväksikäyttö sekä ruokintojen näennäinen sulavuus ruokintajaksolla 2 (elopaino yli $450 \mathrm{~kg}$ ).

\begin{tabular}{|c|c|c|c|c|c|c|c|c|}
\hline & \multicolumn{4}{|c|}{ Ruokinnat $^{\mathrm{a}}$} & \multirow[t]{2}{*}{ SEM $^{b}$} & \multicolumn{3}{|c|}{ Tilastollinen merkitsevyys $^{c}$} \\
\hline & OR0 & OR25 & OR50 & OR75 & & 1 & 2 & 3 \\
\hline Eläinmäärä (kpl) & 8 & 8 & 8 & 7 & & & & \\
\hline Jakson kesto (vrk) & 174 & 168 & 175 & 190 & & & & \\
\hline Rehun syönti (kg ka/pv) & 10,45 & 10,70 & 10,99 & 9,83 & 0,358 & & $*$ & \\
\hline Ry-saanti (ry/pv) & 10,92 & 10,99 & 11,07 & 9,69 & 0,372 & $*$ & $*$ & \\
\hline Oiv-saanti (g/pv) & 1018 & 1030 & 1045 & 922 & 34,4 & o & $*$ & \\
\hline Päiväkasvu (g/pv) & 1203 & 1113 & 1127 & 998 & 53,4 & $*$ & & \\
\hline \multicolumn{9}{|l|}{ Rehun hyväksikäyttö } \\
\hline kg ka/päiväkasvu-kg & 8,69 & 9,74 & 9,80 & 9,89 & 0,301 & $*$ & & \\
\hline ry/päiväkasvu-kg & 9,08 & 10,00 & 9,86 & 9,75 & 0,305 & & o & \\
\hline \multicolumn{9}{|l|}{ Näennäinen sulavuus } \\
\hline Orgaaninen aine & 0,820 & 0,776 & 0,731 & 0,698 & 0,0049 & $* * *$ & & \\
\hline Raakavalkuainen & 0,750 & 0,752 & 0,730 & 0,725 & 0,0074 & $* *$ & & \\
\hline NDF & 0,752 & 0,683 & 0,633 & 0,611 & 0,0109 & $* * *$ & $*$ & \\
\hline
\end{tabular}

${ }^{a}$ Koeruokinnat on esitetty taulukossa 1.

${ }^{\mathrm{b}}$ Keskiarvon keskivirhe.

${ }^{\mathrm{c}}$ Kontrastit: $1=$ ohrarehun lineaarinen vaikutus; $2=$ ohrarehun toisen asteen vaikutus; $3=$ ohrarehun kolmannen asteen vaikutus. Tilastollinen merkitsevyys: *** $\mathrm{P}<0,001$; ** $\mathrm{P}<0,01 ; * \mathrm{P}<0,05$; o $\mathrm{P}<0,10$. 


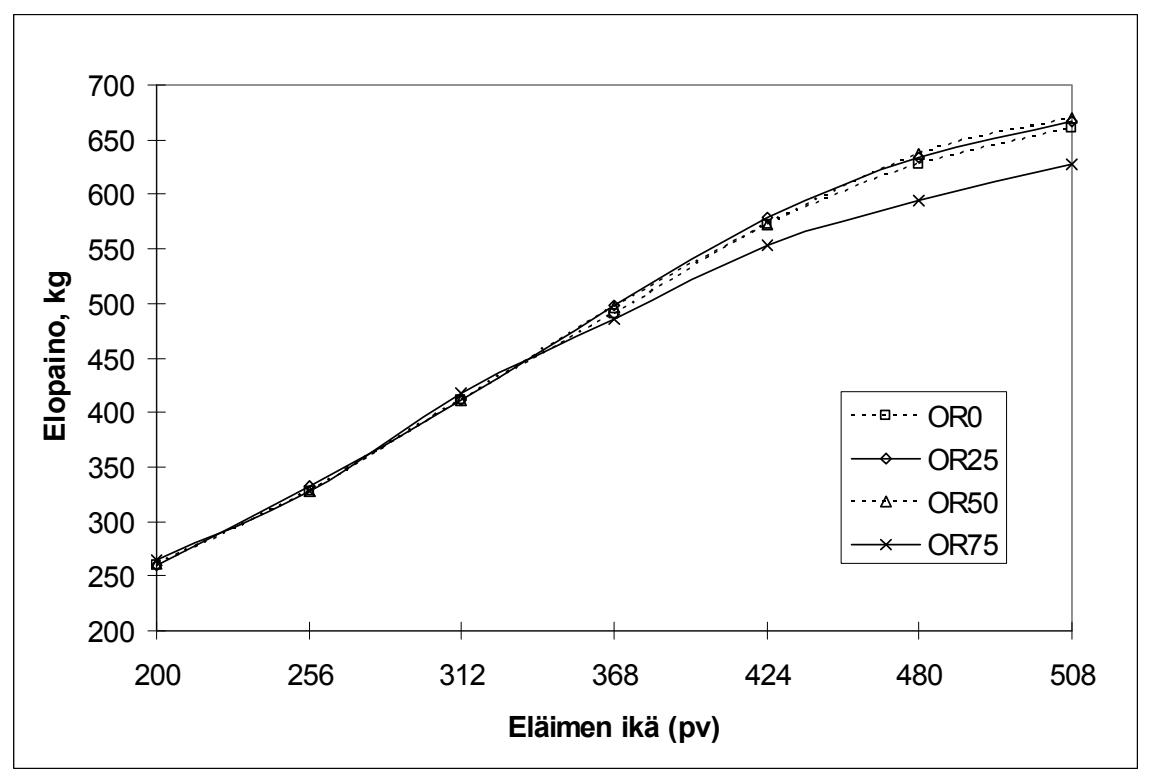

Kuva 1. Sonnien elopainon kehitys (g/pv) eri koeruokinnoilla. Eri koeruokinnat on selitetty taulukossa 1.

\section{Tulosten tarkastelu}

Huhtanen ym. (1989) ja Root ja Huhtanen (1998) eivät havainneet ohran osittaisen korvaamisen ohrarehulla vaikuttavan sonnien rehun syöntiin erillisruokinnalla. Sitä vastoin Huuskosen ym. (2006) kokeessa sonnien rehun syönti lisääntyi 6,5 \%, kun puolet ohrasta korvattiin ohrarehulla seosrehuruokinnassa. Aiemmissa Huhtasen ym. (1989) ja Rootin ja Huhtasen (1998) tutkimuksissa väkirehutasot ja väkirehun keskimääräiset syönnit olivat selvästi matalammat (420 g/kg ka; $2.89 \mathrm{~kg} \mathrm{ka/pv} \mathrm{ja} 390 \mathrm{~g} / \mathrm{kg}$ $\mathrm{ka} ; 3.01 \mathrm{~kg} \mathrm{ka} / \mathrm{pv}$, vastaavasti) kuin tässä raportoitavassa kokeessa $(540 \mathrm{~g} / \mathrm{kg} \mathrm{ka} ; 5.20 \mathrm{~kg} \mathrm{ka} / \mathrm{pv})$ ja Huuskosen ym. (2006) tutkimuksessa (570 g/kg ka; $5.49 \mathrm{~kg} \mathrm{ka} / \mathrm{pv})$. Erot väkirehutasoissa ja väkirehun syöntimäärissä todennäköisesti selittävät tutkimusten välisiä eroavaisuuksia. Ohran korvaaminen ohrarehulla edistää pötsifermentaatiota nimenomaan korkeilla väkirehutasoilla ruokittaessa (Huhtanen ym. 1988), mikä voi osittain selittää lisääntyneen rehun syönnin korkeilla väkirehutasoilla. Toisaalta syönnin lisääntyminen ohrarehua syötettäessä kertoo myös energeettisestä syönnin säätelystä. Ohrarehuseoksia saaneet sonnit pystyivät kompensoimaan seosten hieman heikompaa energia-arvoa OR50ruokinnalle saakka syöntiä lisäämällä. Tällainen energeettinen syönnin säätely on naudalla mahdollista siihen saakka, kunnes pötsin täyteisyys muodostuu rajoittavaksi tekijäksi (Forbes 1995). Syönnin aleneminen OR75-ruokinnalla saattaa johtua ainakin osittain ohrarehun heikosta maittavuudesta suurina annoksina. Huhtasen ym. (1988) kokeessa lypsylehmät eivät syöneet kaikkea tarjottua ohrarehua.

Ohran korvaaminen ohrarehulla heikensi dieetin orgaanisen aineen sulavuutta samalla tavoin kuin aikaisemmissa lihanaudoilla (Huhtanen 1992) ja lypsylehmillä (Huhtanen ym. 1988) tehdyissä ruokintakokeissa. Ohrarehu sisältää selvästi enemmän NDF-kuitua ja vähemmän tärkkelystä kuin ohra, ja ero dieetin orgaanisen aineen sulavuudessa johtuu paremmin sulavan tärkkelyksen korvautumisella heikommin sulavalla kuidulla. Myös NDF:n sulavuus heikkeni, kun ohraa korvattiin ohrarehulla. Yhtenä syynä tähän lienee säilörehun kuidun osuuden suhteellinen vähentyminen, kun dieettiin lisättiin kuitupitoista ohrarehua. Ohrarehun kuitufraktio oli oletettavasti huonommin sulavaa kuin säilörehun kuitu, mikä selittää kuidun sulavuuden heikkenemistä. Lisäksi ohrarehun rasvapitoisuus oli ohraa korkeampi (65 vs. $22 \mathrm{~g} / \mathrm{kg} \mathrm{ka)}$, ja jo suhteellisen pienten rasvalisäysten on tutkimuksissa havaittu heikentävän kuidun sulatusta (Murphy ym. 1987).

Tässä raportoitavassa kokeessa kasvu heikkeni lineaarisesti korvattaessa ohraa ohrarehulla. Kasvutulokset olivat selkeästi heikoimmat $75 \%$ :n korvaustasolla. Sen sijaan kasvutulokset ja elopainokäyrät olivat hyvin samankaltaisia ohrarehutasoilla 0,25 ja $50 \%$. Vaikuttaa siltä, että $75 \%$ :n korvaus osuus oli liian suuri eivätkä sonnit pystyneet kompensoimaan ruokinnan energiapitoisuuden laskua syöntiä lisäämällä, mikä johti heikentyneisiin kasvutuloksiin. Rehun hyväksikäyttö oli ohrarehuruokinnoilla heikompaa kuin OR0-ruokinnalla, koska sonnit joutuivat vastaamaan seoksen energiapitoisuuden laskuun lisääntyneellä syönnillä. 
Ohran osittainen korvaaminen ohrarehulla vähensi ruhojen rasvoittumista lineaarisesti. Kirjallisuuden perusteella ruokinnan energiapitoisuuden pienentäminen vähentääkin yleensä ruhojen rasvoittumista (Schaake ym. 1993), mikä voisi osaltaan selittää matalampaa rasvaluokitusta OR75ruokinnalla. Toisaalta myös teuraspainon nouseminen lisää ruhojen rasvoittumista (Keane ja Allen 1998), ja tässä raportoitavassa kokeessa teuraspaino oli pienin OR75-ruokinnalla, mikä todennäköisesti myös selittää eroja ruhojen rasvaisuudessa. Steen ja Kilpatrick (2000) päätyivät johtopäätökseen, että teuraspainojen madaltaminen on selkeästi tehokkaampi keino rajoittaa ruhojen rasvoittumista kuin energian saannin rajoittaminen tai väkirehun osuuden vähentäminen dieetissä. Tulos pätee tekijöiden mukaan nurmisäilörehuun ja väkirehuun perustuvalla ruokinnalla.

\section{Yhteenveto ja johtopäätökset}

Ohrarehu osoittautui käyttökelpoiseksi energiarehuksi kasvaville lihanaudoille säilörehuohrapohjaisella ruokinnalla. Tutkimustulosten perusteella näyttäisi olevan realistista korvata enintään puolet kasvavan lihanaudan väkirehuannoksesta ohrarehulla. Naudanlihantuottajan kannalta ohrarehun käyttö ruokinnassa muodostuu taloudellisesti järkeväksi, jos sen hinta suhteessa tuotantovaikutukseen on edullisempi kuin muiden käytettävissä olevien väkirehujen.

\section{Kirjallisuus}

AOAC 1990. Official methods of analysis. 15th edition. Associations of Official Analytical Chemists, Arlington, VA. $1298 \mathrm{~s}$.

Forbes, J. M. 1995. Voluntary Food Intake and Diet Selection in Farm Animals. CAB International, Wollingford, UK. $333 \mathrm{~s}$.

Huhtanen, P. 1992. The effects of barley vs. barley fibre with or without distiller's solubles on site and extent of nutrient digestion in cattle fed grass-silage-based diet. Anim. Feed Sci. Tehcnol. 36: 319-337.

Huhtanen, P., Ala-Seppälä, H. \& Näsi, M. 1988. Response of silage intake and milk production to replacement of barley fibre derived from integrated starch-ethanol process. J. Agric. Sci. Finl. 60: 711-721.

Huhtanen, P., Näsi, M. \& Khalili, H. 1989. By-products from integrated starch-ethanol production from barley in the diets of growing cattle. J. Agric. Sci. Finl. 61: 451-462.

Huuskonen, A., Khalili, H. \& Joki-Tokola, E. 2007. Effects of three different concentrate proportions and rapeseed meal supplement to grass silage on animal performance of dairy-breed bulls with TMR feeding. Livest. Sci. 110: 154-165.

Huuskonen, A., Lunki, S. \& Rantanen, A. 2006. Ohrarehun ja ohravalkuaisrehun käyttö lihanautojen ruokinnassa. Teoksessa: Toim. Anneli Hopponen. Maataloustieteen Päivät 2006, 11.-12.1.2006 Viikki, Helsinki [: esitelmät ja posterit]. Suomen maataloustieteellisen seuran tiedote 21: $7 \mathrm{~s}$. http://www.smts.fi/pos06/1203.pdf

McCleary, B.V., Solah, V. \& Gibson, T.S. 1994. Quantitative measurement of total starch in cereal flours and products. J. Cereal Sci. 20: 51-58.

Moisio, T. \& Heikonen, M. 1989. A titration method for silage assessment. Anim. Feed Sci. Technol. 22: 341353.

MTT 2006. Rehutaulukot ja ruokintasuositukset. Verkkodokumentti. Jokioinen: MTT. Julkaistu: 14.2.2006, Viitattu: 1.11.2007. Saatavilla internetistä: http://www.agronet.fi/rehutaulukot/. URN:NBN:fi-fe20041449.

Murphy, M., Uden, P., Palmqvist, D.L. \& Wiktorsson, H. 1987. Rumen and total diet digestibilities in lactating cows fed diets containing full-fat rapeseed. J. Dairy Sci. 70: 1572-1582.

Nousiainen, J., Rinne, M., Hellämäki, M. \& Huhtanen, P. 2003. Prediction of the digestibility of the primary growth of grass silages harvested at different stages of maturity from chemical composition and pepsin-cellulase solubility. Anim. Feed Sci. Technol. 103: 97-111.

Root, T. \& Huhtanen, P. 1998. Barley fibre and wet distillers' solubles in the diet of growing cattle. Agric. Food Sci. Finl. 7: 357-366.

Schaake, S.L., Skelley, G.C., Halpin, E., Grimes, L.W., Brown, R.B., Cross, D.L. \& Thompson, C.E. 1993. Carcass and meat sensory traits of steers finished on fescue and clover, summer forage, or for different periods in drylot. J. Anim. Sci. 71: 3199-3205.

Steen, R.W.J. \& Kilpatrick, D.J. 2000. The effects of the ratio of grass silage to concentrates in the diet and restricted dry matter intake on the performance and carcass composition of beef cattle. Livest. Prod. Sci. 62: 181-192.

Van Keulen, J. \& Young, B.A. 1977. Evaluation of acid-insoluble ash as a marker in ruminant digestibility studies. J. Anim. Sci. 44: 282-287. 